Egyptian Poultry Science Journal

http://www.epsj.journals.ekb.eg/

ISSN: 1110-5623 (Print) - 2090-0570 (Online)

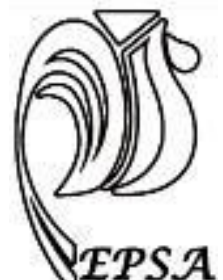

\title{
INFLUENCE OF SUPPLEMENTARY RED BEETROOTS OR BETAINE DIETARY ON PRODUCTIVE PERFORMANCE, BLOOD PROFILES AND ECONOMIC EFFICIENCY OF GROWING RABBITS
}

Aboelfadl M. A., F. N. K. Soliman, O. A. Elghalid and A. M. Abd El-Hady*

Fac. of Agric. (El-Shatby), Poult. Prod. Dep. Alexandria Uni., Alexandria 21545, Egypt

*Correspondence author: A. M. Abd El-Hady Email:ahmed75atta@ yahoo.com

Received: 08/08/2020 Accepted: 01 /09/2020

\begin{abstract}
The present study aimed to investigate the effect of dried red beetroots and commercial betaine on blood hematology, lipid profile and immunity status of growing rabbits. A total of 150, unsexed Alexandria line weaned rabbits, at 4 weeks of age were randomly divided into five groups (30 rabbits each). Rabbits in the first group were fed the control diet, while those in groups $2^{\text {nd }}, 3^{\text {rd }}, 4^{\text {th }}$ and $5^{\text {th }}$ were fed on $0.5 \%$, $1.0 \%$ of dried red beet, $0.1 \%$ and $0.2 \%$ of commercial betaine, respectively for 5 weeks. Data revealed that treatment groups with dried red beetroots and commercial betaine recorded the higher live body weight at 9 weeks of age, body weight gain, feed consumption from 4 to 9 weeks and improved feed conversion and mortality rate compared to control group. Red blood cells, hemoglobin and packed cell volume was increased significantly compared to control group. All treatments and increasing red beetroots and betaine levels resulted in high in white blood cells, lymphocyte, total protein, globulin and high density lipoprotein levels compared to control, but, total lipids, cholesterol, triglyceride and low density lipoprotein values decreased significantly. Liver enzymes and kidney function levels were improved in treatment groups compared to the control group. With dried red beetroots physiological status of growing rabbits was showed an enhanced compared to commercial betaine. The results of economic efficiency indicated that the Alexandria growing rabbit fed $0.5 \%$ dried red beetroots has highest relative economic efficiency compared to control, $3^{\text {nd }}, 4^{\text {rd }}$ and $5^{\text {th }}$ $(108.10,103.47,104.72$ and $98.79 \%$, respectively). These findings revealed that $0.5 \mathrm{~kg} /$ $100 \mathrm{~kg}$ diet may exert beneficial effects on productive performance, hematology parameters, lipid profile and economic efficiency properties of growing rabbits.
\end{abstract}

Keywords: Beetroots; Betaine; Productive performance; Lipid profile; Rabbits 
Aboelfadl M. A. et al.

\section{INTRODUCTION}

Plant-derived supplements are used to maintain the growth performance of livestock animals (Ashour et al., 2014). The use of diets rich in natural antioxidants as a means of removing excessive free radicals from the animal's body (Li et al., 2018), and for normal physiological processes in animals (Lee et al., 2017), is becoming popular/ essential. Red beet is a rich source of polyphenols together with the betaine (Bet), demonstrating a high antioxidant effect and radical scavenging capacity, which possess many health positive effects (Nestora et al., 2016). Therefore, Hussein et al. (2016) suggested the use of new by-products of processed sugar to be included in poultry diets to enhance growth performance in areas where an abundance of this sugar mill by-product is available.

The Bet has the potential to improve nutrient digestibility by supporting the broilers growth, since it stimulate cell proliferation in the intestinal tissue, the enlarged gut wall epithelium which provide an increase surface for nutrient absorption and then affects the body weight (Ratriyanto et al., 2009). Also, Bet supplementation significantly improved feed conversion ratio (FCR) in rabbits (Hayam Abo EL-Maaty et al., 2017), broiler chickens (Chand et al., 2017) and ducks (Wang et al., 2004). However, Sakomura et al. (2013) found that different studied Bet supplementations did not significantly affect feed consumption (FC) and FCR of broiler chickens.

El-Shinnawy (2015) evaluated the influence of supplementing Bet to broiler diets containing adequate concentration of methionine, found that supplementation with Bet led to significant increases in serum concentrations of total protein and globulin. Due to its special molecular structure, Bet is also an efficient methyl donor. The trans-methylation of Bet is used in many biochemical pathways including the methionine-homocysteine cycle and the biosynthesis of carnitine and phospholipids (Figueroa et al., 2018). Thus, Bet plays an important role in lipid metabolism including decrease of hepatic triglyceride accumulation (Xu et al., 2015). In general, dietary Bet may affect the levels of cholesterol in plasma and different tissues of animal bodies.

Most of the studies on red beets have been directed to human health features, as well as the studies of Bet directed to its advantages in preventing chicken heat stress. Therefore, the objectives of this study was to evaluate the effects of adding two sources of antioxidants dried red beetroot and commercial betaine to the diet of growing Alexandria rabbits line on productive performance, blood characteristics and economic efficiency.

\section{MATERIALS AND METHODS}

The present study was carried out at the Poultry Research Center, Faculty of Agriculture, Alexandria University, during the period from March to April 2017 .

\section{Animal care}

All animal care procedures were approved by the Institutional Animal Care and Use Committee in AU-IACUC, Alexandria University, Egypt. Authors adhere the procedures imposed on the animals have been implemented in accordance with Directive 2010/63/EU of the European Parliament and of the Council of 22 September 2010 on the protection of animals used for scientific purposes. Authors also adhere to the EU regulations on feed legislation, the 
Beetroots; Betaine; Productive performance; Lipid profile; Rabbits

'Regulation (EC) No 767/2009 of the European Parliament and of the Council of 13 July 2009 on the placing on the market and use of feed.

Dried red beetroots

Dried red beetroots (RBR) harvested 7-8 month were washed with tap water, chopped into small pieces and then dried at solar energy for 3 days. The dried material was reduced into powder form as far as possible and powdered using a lab grinder and stored at $4^{\circ} \mathrm{C}$ till use (Rabeh, 2015). The practical nutrition analysis of RBR was found in Table 1.

\section{Commercial Betaine}

The commercial source of chemical Bet used in the present experiments was "Betafen". Betafin ${ }^{\circledR}$ natural betaine is extracted from sustainable sugar beet molasses and vinasses (fermented molasses) using a patented chromatographic separation process.

\section{Alexandria rabbit line}

Alexandria line is a synthetic paternal rabbit line which was established and progressing at the nucleus breeding rabbit unit of the Poultry Research Center, Alexandria University, Egypt. This line was originated by crossing a V-line with a Baladi Black rabbits (El-Raffa et al., 2005). The line is being individually selected for daily gain between weaning (28d) and slaughter (63d).

\section{Experimental design}

A total of 150 weaned unsexed Alexandria line rabbits, aged four weeks and averaged $610 \mathrm{~g}$ body weight, were randomly allocated into five experimental groups each of 30 rabbits. Each group was further subdivided into 10 replicates of 3 rabbits each. All rabbits were nearly similar in live body weight in treatments, fed ad libitum until marketing at 63 days of age and water was accessible all the time. Rabbits in the control were fed a basal diet without supplementation, while those in groups 2nd, 3rd, 4th and 5th were fed a basal diet containing dried red beet at levels of $0.5 \%$ and $1.0 \%$ or Bet at levels of $0.1 \%$ and $0.2 \%$, respectively. All experimental groups were fed the basal diet was formulated to cover all essential nutrient needs of growing rabbits (NRC, 1994), containing $17.27 \%$ crude protein and digestible energy $2640 \mathrm{kcal} / \mathrm{kg}$.

\section{Housing and management}

Growing rabbits were housed in wellventilated open system rabbitry made of galvanized $(50 \times 45 \times 40 \mathrm{~cm})$ wire cages with gridded wire floor to completely separate rabbits from excreta. All rabbits were kept under the same managerial, hygienic and environmental conditions, at controlled average range of ambient temperature $20-23{ }^{\circ} \mathrm{C}$, relative humidity 60-73\% and day-light length during the five weeks of the experimental period (March to the end of April) $10 \mathrm{~h} 24 \mathrm{~min}$ to $11 \mathrm{~h} 46 \mathrm{~min}$.

All cages were provided with manual feeders and accessible clean fresh water through an automated system of nipple drinkers. Cages properly cleaned and disinfected regularly. After each kindling, urine and feces were dropped from cages on the building floor were collected every day morning and removed outside the house .

\section{Data collected}

Individual rabbit live body weights (BW), body weight gain (BWG), FC and FCR for the experimental period were recorded at the start and end of the experimental period. The dead rabbits were recorded during the whole experimental period for each treatment, and then the mortality rate (MR) was calculated as number of dead rabbits at the end of the experiment to the number of rabbits the beginning of the study. About $3 \mathrm{ml}$ of blood samples 
were collected between $8.00-9.00 \mathrm{~h}$ a.m. at 63 days of age from the marginal ear vein into vacationer tubes with or without containing K3-EDTA (1 $\mathrm{mg} / \mathrm{ml})$. Coagulated and non-coagulated blood samples after centrifuged at $4000 \mathrm{rpm}$ for 15 minutes and the clear serum and plasma were separated and stored frozen at $-20^{\circ} \mathrm{C}$ until biochemical analysis. Fresh blood samples were analyzed shortly after collection for hematological parameters. Counts of red blood cells (RBCs $\left.10^{6} / \mathrm{mm}^{3}\right)$ and WBCs $\left(10^{3} / \mathrm{mm}^{3}\right)$, hemoglobin $(\mathrm{Hb})$ concentration $(\mathrm{g} / \mathrm{dl})$ and packed cell volume (PCV \%) were determined and its differential counts lymphocyte (L), neutrophils (N) and the ratio between them (N/L) according to (Feldman et al., 2000).

Plasma total protein and albumin (AL, $\mathrm{g} / \mathrm{dl})$ measured using special kits delivered from sentinel $\mathrm{CH}$ Milano, Italy by means of spectrophotometer (Beckman DU-530, Germany). With the difference between total protein and $\mathrm{AL}$ the blood globulin (GL) level (g/dl) was calculated as fibrinogen usually contains a small fraction. AL per GL ratio was calculated by divided Al per GL. Serum concentration of total lipids (TL), cholesterol (Chol), triglyceride (TG), high density lipoprotein (HDL) and low density lipoprotein (LDL) (mg/dl) were assessed calorimetrically using commercial kits (Biosystems S.A. Costa Brava, Barcelona, Spain). The transaminase enzymes activities of serum aspartate amino transferase (AST), alanine amino transferase (ALT) and alkaline phosphatase (ALP) levels were determined by calorimetric method. Serum creatinine and uric acid were assayed by a colorimetric method using commercial kits of Sclavo Diagnostics Company (Kite Italia S.P.A.).

\section{Economic efficiency}

Economic efficiency of production was calculated from the input-output analysis of the money, based on the differences in both growth rate and feeding costs. The value of the economic efficiency was calculated as the net revenue per unit of total feed costs. The prices of experimental diets and live body weight were calculated according to the prices of the local Egyptian market at the time of experiment in 2018, according to the formula of (Riad et al., 2010).

Net Revenue $=$ Total Revenue - Total feed cost

Economic efficiency $=$ Net Revenue $/$ Total feed cost $\mathrm{x} 100$

Relative economic efficiency $(\%)$ affecting the control treatment $=100 \%$

\section{Statistical analysis}

The statistical analyses were carried out using a completely randomized design. Data were analyzed by analysis of variance using the general liner model procedure (SAS, 2004). Data on the traits studied were subjected to analysis of variance using the following model: $\mathrm{Y}_{\mathrm{ijk}}=$ $\mu+\mathrm{T}_{\mathrm{i}}+\mathrm{Y}_{\mathrm{j}}+\mathrm{e}_{\mathrm{ijk}}$ in which $\mathrm{Y}_{\mathrm{ijk}} \mathrm{i}$ is each dependent variable under study, $\mu$ is the overall mean, $\mathrm{Ti}$ is the fixed effect of the $i^{\text {th }}$ treatments of red beet ( $i$ from 1 to 2), $Y_{j}$ is the fixed effect of the $j^{\text {th }}$ treatments of commercial betaine ( $j$ from 1 to 2 ) and $\mathrm{e}_{\mathrm{ijk}}$ is the random residue error. Duncan's multiple range tests was used to detect any significant differences among the experimental means (Duncan, 1955). The statistical significance was accepted at $\mathrm{P} \leq$ 0.05 .

\section{RESULTS AND DISCUSSIONS Productive performance}

The results in table 2 showed that showed significant differences in control vs. treatments comparison for 9-week BW $(\mathrm{P} \leq 0.01)$ by $5.35 \%$ and $4-9$-week BWG 
Beetroots; Betaine; Productive performance; Lipid profile; Rabbits

$(\mathrm{P} \leq 0.001)$ by $8.27 \%$, while it is insignificant $(\mathrm{P} \geq 0.05)$ in the other comparisons (RBR $0.5 \%$ vs. RBR $1 \%$, Bet $0.1 \%$ vs. Bet $0.2 \%$ and RBR vs. Bet). The RBR and Bet treatments have significantly higher $\mathrm{BW}$ and BWG compared to corresponding values of control group. Although there are no significant $(\mathrm{P} \geq 0.05)$ differences, the increase of both experimental antioxidant sources level has slight positive effect on the final BW and BWG of growing rabbits. Also, the comparison of dried RBR vs. Bet showed enhancer effect on BW and BWG in favor of dried RBR.

The results of dried RBR are in agreement with the finding of Hayam Abo EL-Maaty et al. (2017) who made different sugar beet tops (SBT) substitution in rabbit diets was produced positive effects on growth performance although feed intake was higher than that of the control group. However, El-Taweel (2010) diet did not found that BWG influences by different studied sugar beet pulp (SBP) substitutions in rabbit diets. Moreover, Abedo et al. (2012) showed that total and daily BWG were significantly decreased with SBP substitutions diets and both values were progressively lowered with the diet contained 50\% SBP of corn diet.

The results of Bet are in agreement with the finding of Hassan et al. (2011) and Abd El-Moniem et al. (2016) who showed significant enhancer effect of dietary Bet on BW and BWG of NZW growing male rabbits. Also, Abd ElAzeem et al. (2019) found that daily BWG during 5-13 weeks of age was significantly increased in NZW growing male rabbits fed Bet supplemented diets (750 and $1500 \mathrm{mg} / \mathrm{kg}$ ) compared to control group $(33.28,35.76$ and $30.17 \mathrm{~g}$, respectively).
The RBR and Bet treatments have significantly higher 4-9weeks FC by $3.09 \%$ and better FCR by $5.23 \%$ compared to corresponding values of control treatment. Although there are no significant differences, the increase of beetroot level increase the 4-9weeks FC, while the results of 4-9weeks FCR found to be improved with the increase of RBR level while opposite trend was found with Bet. The RBR was useful to improve FCR more than Bet.

The present results of dried RBR are in agreement with the finding of Shehata and Bahgat (2006) who reported that SBP in diets increased FC for growing rabbits when $25 \%$ of whole diet was replaced by SBP. Hayam Abo EL-Maaty et al. (2017) found that replacing alfalfa hay with SBT $(0,20$ and $30 \%)$ of NZW rabbits during 6-12 weeks of age increased significantly FC than that of control group and FCR value was improved significantly. Also, El-Taweel (2010) showed slight FC increase by different studied SBP substitutions in rabbit diets. However, Aboul-Ela and Reda (2016) reported that SBP reduced FC of rabbits. Considering rabbit FCR trait, the SBP substitution has improved FCR as showed by Abedo et al. (2012) and Aboul-Ela and Reda (2016). In contrary, Shehata and Bahgat (2006) and El-Taweel (2010) found that SBP substitutions rabbit diets improved FCR.

In regard to Bet supplementation, Hassan et al. (2011) showed that NZW growing male rabbits fed Bet supplementation (750 and $1000 \mathrm{mg}$ Bet $/ \mathrm{kg}$ ) increased significantly FC compared to control group. However, Abd El-Azeem et al. (2019) found that FC of NZW growing male rabbits not significant affected by different dietary supplementation include Bet. They indicated that FCR and economic efficiency recorded the best 
Aboelfadl M. A. et al.

results with rabbits fed $1500 \mathrm{mg}$ Bet $/ \mathrm{kg}$ in their diet.

The results showed significant differences in control vs. treatments comparison for 4-9weeks mortality rate $(\mathrm{P} \leq 0.05)$, while it is insignificant in the other studied comparisons (Table 1). The RBR and Bet treatments have significantly better MR value by $50 \%$ compared to control treatment value $(3.33$ and $6.67 \%$, respectively). The both antioxidant sources and their levels had no effect on MR of growing rabbits.

In respect of $\mathrm{RBR}$, the results are in agreement with the findings of Aboul-Ela and Reda (2016) and Hayam Abo ELMaaty et al. (2018) who showed that the inclusion of SBP in rabbit diets by different levels improved viability of the fattening rabbits.

The good performance of rabbits shown in the present study may be due to the phytochemicals present in RBR and Bet properties which have direct or indirect effects on animal metabolism, likely by making modification of animal metabolism in favor to increase their positive performance (ValenzuelaGrijalva et al., 2017). In addition, the use of diets rich in natural antioxidants as a means of eliminating excessive free radicals from the animal's body and then alleviation of high-temperature negative effects on animal production is becoming popular (Li et al., 2018).

\section{Blood Constituents}

\section{Hematological parameters}

The results of erythorcytic parameters (Table 3) showed highly significant differences in control vs. treatments comparison for $\mathrm{RBC}^{\prime} \mathrm{s} \quad(\mathrm{P} \leq 0.01), \mathrm{Hb}$ $(\mathrm{P} \leq 0.001)$ and $\mathrm{PCV}(\mathrm{P} \leq 0.01)$ values. The RBR and Bet treatments have significantly higher RBC's, $\mathrm{Hb}$ and PCV values by $17.23,8.04$ and $8.28 \%$, respectively compared to corresponding values of control treatment. The results found to be insignificant for the three erythrocytes parameters between RBE treatments and Bet treatments. In regard to RBR vs. Bet comparison, showed positive significant effect only on RBC's $(\mathrm{P} \leq 0.001)$ and $\mathrm{PCV} \%(\mathrm{P} \leq 0.05)$ values, in favor to dried RBR by 14.67 and $4.60 \%$, respectively compared to Bet treatments.

The present results of leukocytes parameters (Table 3) showed significant differences in control vs. treatments comparison for WBCs $(\mathrm{P} \leq 0.05), \quad \mathrm{L}$ $(\mathrm{P} \leq 0.01), \quad \mathrm{N} \quad(\mathrm{P} \leq 0.01)$ and $\mathrm{N} / \mathrm{L}$ ratio $(\mathrm{P} \leq 0.01)$ values, while it is insignificant in the other studied comparisons. The RBR and Bet treatments have significant higher WBC's and $\mathrm{L}$ values by 13.18 and $16.02 \%$, respectively and significant lower $\mathrm{N}$ and $\mathrm{N} / \mathrm{L}$ ratio values by 12.36 and $23.31 \%$, respectively compared to corresponding values of control treatment.

The hematological values obtained in the present results across the treatments were within the normal range for rabbit's blood (NseAbasi Etim et al., 2014). Abd ElAzeem et al. (2019) showed that RBCs, $\mathrm{Hb}$, Haematocrit, WBCs and L parameters of NZW growing male rabbits did not significant affected by different dietary supplementation include Bet.

\section{Blood biochemical parameters}

The results of studied protein profile traits (Table 4) showed significant differences in control vs. treatments comparison for only total protein $(\mathrm{P} \leq 0.01)$ value, while it is insignificant in the other studied comparisons for $\mathrm{Al}$, GL and AL/GL ratio. The RBR and Bet treatments have significant higher total protein value by $9.16 \%$ compared to corresponding value of control treatment. In respect of $\mathrm{Al}, \mathrm{GL}$ and AL/GL ratio values, the results 
Beetroots; Betaine; Productive performance; Lipid profile; Rabbits

showed insignificant differences within all studied comparisons.

The values of plasma protein profile of growing rabbits in the present study are within the range of reference values reported for healthy rabbits in previous studies (NseAbasi Etim et al., 2014). Hassan et al. (2011) found that serum total protein and GL values were significantly increased due to dietary Bet, however AL value was not affected. Kurchaeva et al. (2019) noted that total protein was increased of growing rabbits fed girasole beet pulp from 45 to 120 days, by 8.52 and $6.54 \%$. However, Abedo et al. (2012) found that blood total protein of NZW rabbits was decreased significantly with diets contained SBP (25 or $50 \%)$. Also, the current results were higher than the corresponding values of Sara Sherif et al. (2019) who reported slight lower protein profile values (total protein, AL and GL) values in their control groups for NZW rabbits at 14 weeks of age. While, Hayam Abo ElMaaty et al. (2017) who observed that feeding the SBT-containing diets did not alter plasma concentrations of total protein and AL of 12 weeks old NZW rabbits compared with the control group. But rabbits fed the diet containing the highest level of SBT (30\%) exhibited significantly higher blood plasma level of GL than that of their control counterparts. In the present results of studied lipids profile traits (Table 4) showed significant differences in control vs. treatments comparison for TL (TL, $\mathrm{P} \leq 0.05)$, Chol (Chol, $\mathrm{P} \leq 0.05)$, TG (TG, $\mathrm{P} \leq 0.05)$, LDL $(P \leq 0.01)$ and HDL $(P \leq 0.01)$ values. The RBR and Bet treatments have significant higher HDL value by $19.62 \%$, and significant lower TL, Chol, TG and LDL values by $9.09,12.10,10.27$ and $19.10 \%$, respectively compared to corresponding values of control group. The results of all of lipids profile traits showed insignificant differences in other studied comparisons (RBR $0.5 \%$ vs. RBR $1 \%$, Bet $0.1 \%$ vs. Bet $0.2 \%$ and RBR vs. Bet). In general, the level of studied lipids profile parameters are within the corresponding reference values in literature for healthy rabbits (Kaneko, 1989 and Belabbas et al., 2019). However, the current results were higher than the corresponding values of Sara Sherif et al. (2019) who reported lower TG $(61.62$ and $61.88 \mathrm{mg} / \mathrm{dL}$, respectively), Chol (78.50 and 79.84 $\mathrm{mg} / \mathrm{dL}$, respectively) and HDL (24.93 and $28.11 \mathrm{mg} / \mathrm{dL}$, respectively) values in their control groups for NZW rabbits at 14 weeks of age.

The current lipid profile values are in line with the finding of Abedo et al. (2012) found that blood serum $\mathrm{TG}$ and Chol values of NZW growing rabbits were decreased $(\mathrm{P} \leq 0.01)$ with diets contained SBP (25 or $50 \%)$. Oloruntola et al. (2016) with rabbits, recorded reduction of serum Chol level with diets containing 50 or 100 $\mathrm{g} / \mathrm{kg}$ alchornea leaf meal. However, Hayam Abo El-Maaty et al. (2018) showed insignificant effects the plasma concentrations of TL and Chol values in examined rabbit fed SBT at levels 0.0, 20 or $30 \%$.

While, Hassan et al. (2011) showed that serum TL level of NZW growing male rabbits fed 0, 250, 500, 750 and $1000 \mathrm{mg}$ Bet/kg diet treatments was significantly increased due to dietary Bet $(2.67,3.22$, $3.36,3.40$ and $3.29 \mathrm{mg} / \mathrm{dL}$, respectively), while Chol values was not affected (ranged between 89.90 and $91.24 \mathrm{mg} / \mathrm{dL}$ ). The red beetroots phytochemicals contained Saponins (Mroczek et al., 2012), were linked to the reduction of cholesterol uptake in the gut (Yilkal, 
Aboelfadl M. A. et al.

2015). On the other hand, Bet has been shown to regulate hepatic Chol metabolism. Earlier studies reported significant roles of Bet as improving growth performance and fat metabolism (Saeed et al., 2017).

The results of liver function indicators (Table 5) showed significant differences in control vs. treatments comparison for AST $(\mathrm{P} \leq 0.01)$, ALT $(\mathrm{P} \leq 0.01)$ and ALP $(\mathrm{P} \leq 0.05)$ activities. The RBR and Bet treatments have significant higher ALP activity by $16.20 \%$, and significant lower AST and ALT values by 17.04 and $18.85 \%$, respectively compared to corresponding activities of control group. In respect of both level comparisons, the effect was insignificant for all studied indicators. However, the RBR vs. Bet comparison showed highly significant $(\mathrm{P} \leq 0.01)$ effect on only AST activity, since rabbits fed RBR groups have lower AST activity compared to those fed Bet treatments $(36.17$ and $42.20 \mathrm{U} / \mathrm{L}$, respectively).

Abedo et al. (2012) found that liver ALT and AST were insignificantly influenced by feeding SBP diets (25 or $50 \%$ ) of NZW rabbits. Hayam Abo EL-Maaty et al. (2018) concluded that NZW rabbits fed SBT at different levels $(0.0,20$ or $30 \%$ ) in their diets did not alter plasma concentrations of AST and ALT activities at 12 weeks of age. Hassan et al. (2011) found that serum ALP level in the NZW growing male rabbits fed $0,250,500,750$ and $1000 \mathrm{mg}$ Bet $/ \mathrm{kg}$ diet treatments were significantly decreased due to dietary Bet (22.50, 18.63, 16.00, 14.33 and 13.70 IU/l, , respectively). Compared to the present results, the findings of Sara Sherif et al. (2019) were higher for AST (52.10 and $65.10 \mathrm{U} / \mathrm{l}$, respectively) and lower ALT (12.65 and 15.69 U/l, respectively) values in their control groups for NZW rabbits at 14 weeks of age.

Serum enzymes activity (AST and ALT) may be adversely affected by factors such as muscular injury, rupture of organs, nutritional status, physical activity, hemolysis, treatment, and conservation of plasma samples, and their levels in blood can increase. These enzymes can be an important diagnostic tool in veterinary medicine (Harr, 2002).

The highly significant AST and ALT enzyme activities found in the present study (Table 4) could be indicate that the Bet treatments (T4 and T5) of higher AST and ALT values compared to both beetroot treatments (T2 and T3) changed tissue development and modifications of studied rabbits as attributed by high serum enzyme activity, as illustrated by Moniello et al. (2005) in their study with broiler chickens. On the other wards, the Bet treatments increased the liver enzyme activities while beetroot treatments decrease them.

The results of kidney function indicators (Table 5) showed highly significant $(\mathrm{P} \leq 0.001)$ differences in control vs. treatments comparison for creatinine value, while it is insignificant for uric acid value. The RBR and Bet treatments have lower significant creatinine by 22.77 $\%$ and insignificant uric acid values compared to corresponding values of control group. In respect of both level comparisons, the effect was insignificant for both studied indicators. However, the RBR vs. Bet comparison showed significant effect $(\mathrm{P} \leq 0.05)$ on only creatinine value, since rabbits fed Bet treatments have significant lower creatinine value compared to those fed RBR treatments $(0.74$ and $0.82 \mathrm{mg} / \mathrm{dL}$, respectively). 


\section{Beetroots; Betaine; Productive performance; Lipid profile; Rabbits}

The obtained creatinine and uric acid values are in line with the findings of Elwasife et al. (2015) with rabbits. The present kidney indicators parameter values are in line with the finding of Hayam Abo EL-Maaty et al. (2018) who showed that feeding SBT at levels 0.0, 20 or $30 \%$ to replace 50 or $75 \%$ of dietary alfalfa hay did not alter plasma concentrations of Urea (11.70, 11.73 and $11.63 \mathrm{~g} / \mathrm{dL}$, respectively), while decreased significantly creatinine level in SBT treatments (1.180, 1.007 and 1.002 $\mathrm{mg} / 100 \mathrm{~mL}$, respectively) of 12 -week-old NZW rabbits. The opposite trend was found by Abedo et al. (2012) who showed that blood serum uric acid values were decreased significantly, while creatinine values were insignificantly influenced by feeding SBP diets (25 or $50 \%$ ) of NZW rabbits.

Generally, the results reflect that the rabbits fed different studied supplementations have normal kidney functions. However, Bet treatments were more effective than dried RBR treatments in reducing creatinine values of growing rabbits.

\section{Economic efficiency}

The results of economic efficiency indicated that the Alexandria growing rabbit fed $0.5 \%$ dried RBR (T2) has highest economic efficiency compared to control, T3, T4 and T5 (140.50, 129.97,134.48, 136.10 and $128.40 \%$, respectively), as shown in Table 6 . The corresponding relative economic efficiency to control value was 108.10 , 103.47, 104.72 and $98.79 \%$. These results suggested the use of one of $0.5 \%$ dried RBR, $1 \%$ dried RBR or $0.1 \%$ commercial Bet supplementations in growing rabbit diets during 4 and 9 weeks of age, with positive effects on productive performance. These results also, indicated that the use of $0.5 \%$ dried red beetroots, which are more available and cheaper, has higher profitable economical effect among all studied treatments. The Bet improves energy efficiency, growth, economic performance and carcass quality (Chand et al., 2017). Yusuf et al. (2018) showed that dietary organic Bet (0 , 1.5 and $3.0 \mathrm{~g}$ Bet $/ \mathrm{kg}$ diet) Arbor Acre Plus males from 21-42 days of age, Bet is recommended in finishing male broilers as production costs were reduced by $3.97-4.37 \%$ per kg, respectively. Shimaa Amer (2018) showed that Bet can be included in normal energy diets of broiler chickens by level of $2 \mathrm{~g} / \mathrm{kg}$ diet for improving the growth performance, economic value and welfare during the summer season. Awad (2019) who indicated that the Cobb 500 broiler chicks fed $0.75 \mathrm{~kg}$ Bet has higher economic efficiency.

\section{CONCLUSION}

It was concluded that the supplementation of dried red beetroots powder and betaine to the diet could improve growth performance, lipid profile, liver and kidney functions indicators in the blood and economic efficiency of growing rabbits. Nevertheless, the range for optimal inclusion of dried red beetroots $0.5 \mathrm{~kg} / 100 \mathrm{~kg}$ diet has been shown to have a beneficial impact on the growth and feed conversion ratio of growing rabbits. Considering the vast improvement in growth performance and economic efficiency, the Inclusion of dried red beetroots up to $0.5 \%$ of total diet is recommended.

\section{ACKNOWLEDGEMENTS}

The authors wish to thank "nucleus breeding rabbit unit" of the Poultry Research Center, Poultry Department, Faculty of Agriculture, Alexandria University, Egypt for providing the rabbit 
Aboelfadl M. A. et al.

line and part of the laboratory tools, experiment. This research did not receive chemicals and supervising the any specific funding.

Table (1): The nutrition analysis of dried red beetroot used in the experiments.

\begin{tabular}{|l|c|}
\hline \multicolumn{1}{|c|}{ Nutrients } & Content \\
\hline Protein (\%) & 16.6 \\
Fat $(\%)$ & 1.67 \\
Fiber $(\%)$ & 8.88 \\
Ash $(\%)$ & 17.54 \\
Water (\%) & 8.47 \\
Total Betalains (mg/100g) & 249.76 \\
Betacyanins $(\mathrm{mg} / 100 \mathrm{~g})$ & 154.72 \\
Betaxanthins $(\mathrm{mg} / 100 \mathrm{~g})$ & 95.04 \\
\hline
\end{tabular}

Table (2): Means \pm standard error of performance traits of Alexandria growing rabbits fed diets supplemented with different levels of dried red beetroots or commercial betaine.

\begin{tabular}{|l|c|c|c|c|c|}
\hline \multirow{2}{*}{ Comparisons } & \multicolumn{5}{c|}{ Performance Traits } \\
\cline { 2 - 6 } & $\begin{array}{c}\text { BW } \\
\text { at 9 wk (g) }\end{array}$ & $\begin{array}{c}\text { BWG } \\
\mathbf{4 - 9} \mathbf{~ w k}(\mathbf{g})\end{array}$ & $\begin{array}{c}\text { F-9 } \mathbf{~ w k}(\mathbf{g}) \\
\mathbf{4 - 9} \mathbf{~ w k}\end{array}$ & $\begin{array}{c}\text { Mortality } \\
\text { rate (\%) }\end{array}$ \\
\hline Control & 1819.87 & 1208.20 & 3648.00 & 3.02 & 6.67 \\
Treatments & 1917.17 & 1308.12 & 3760.58 & 2.87 & 3.33 \\
P-value & 0.003 & 0.001 & 0.001 & 0.010 & 0.041 \\
\hline Significance & $* *$ & $* * *$ & $* * *$ & $*$ & $*$ \\
\hline Beet root 0.5\% & 1922.33 & 1314.00 & 3758.30 & 2.86 & 3.33 \\
Beet root 1\% & 1936.00 & 1328.67 & 3772.90 & 2.84 & 3.33 \\
P-value & 0.735 & 0.644 & 0.636 & 0.753 & 0.481 \\
\hline Significance & $\mathrm{NS}$ & $\mathrm{NS}$ & $\mathrm{NS}$ & $\mathrm{NS}$ & $\mathrm{NS}$ \\
\hline Betaine 0.1\% & 1900.67 & 1290.17 & 3733.00 & 2.89 & 3.33 \\
Betaine 0.2\% & 1909.67 & 1299.63 & 3778.10 & 2.91 & 3.33 \\
P-value & 0.824 & 0.765 & 0.145 & 0.911 & 0.585 \\
\hline Significance & $\mathrm{NS}$ & $\mathrm{NS}$ & $\mathrm{NS}$ & $\mathrm{NS}$ & $\mathrm{NS}$ \\
\hline Beet root & 1929.17 & 1321.33 & 3765.60 & 2.85 & 3.33 \\
Betaine & 1905.17 & 1294.90 & 3755.55 & 2.90 & 3.33 \\
P-value & 0.401 & 0.239 & 0.645 & 0.231 & 0.810 \\
\hline Significance & $\mathrm{NS}$ & $\mathrm{NS}$ & $\mathrm{NS}$ & $\mathrm{NS}$ & $\mathrm{NS}$ \\
\hline SE Mean & 27.66 & 0.239 & 20.99 & 0.05 & 0.20 \\
\hline
\end{tabular}

Different letters (a-b) in the same column and comparison indicate significant differences ( $\mathrm{P} \leq 0.05)$.*, Significant at $\mathrm{P} \leq 0.05$; **, Significant at $\mathrm{P} \leq 0.01 ;$ N.S, not significant.

BW, body weight; BWG, body weight gain; FC, feed consumption; FCR, feed conversion ratio. 
Beetroots; Betaine; Productive performance; Lipid profile; Rabbits

Table (3): Means \pm standard error of Hematological characteristics of Alexandria growing rabbits fed diets supplemented with different levels of dried red beetroots or commercial betaine.

\begin{tabular}{|c|c|c|c|c|c|c|c|}
\hline \multirow[b]{2}{*}{ Comparisons } & \multicolumn{3}{|c|}{ Erythorcytic parameters } & \multicolumn{4}{|c|}{ Leukocytic parameters } \\
\hline & $\begin{array}{c}\text { RBC's } \\
\left(10^{6} / \mathrm{cmm}^{3}\right)\end{array}$ & $\begin{array}{c}\mathbf{H b} \\
(\mathrm{g} / \mathrm{dL})\end{array}$ & $\begin{array}{c}\text { PCV } \\
(\%)\end{array}$ & $\begin{array}{c}\text { WBC's } \\
\left(10^{3} / \mathrm{cmm}^{3}\right)\end{array}$ & $\begin{array}{c}\text { Lymphocyte } \\
(\%)\end{array}$ & $\begin{array}{c}\text { Neutrophils } \\
(\%)\end{array}$ & $\begin{array}{l}\mathrm{N} / \mathrm{L} \\
\text { ratio }\end{array}$ \\
\hline Control & 4.12 & 10.32 & 32.48 & 5.84 & 33.96 & 55.20 & 1.63 \\
\hline Treatments & 4.83 & 11.15 & 35.17 & 6.61 & 39.40 & 48.38 & 1.25 \\
\hline $\mathrm{P}$-value & 0.001 & 0.001 & 0.004 & 0.028 & 0.005 & 0.007 & 0.001 \\
\hline Significance & $* *$ & $* * *$ & $* *$ & $*$ & $* *$ & $* *$ & $* *$ \\
\hline Beet root $0.5 \%$ & 5.08 & 11.20 & 35.60 & 6.44 & 36.96 & 50.26 & 1.36 \\
\hline Beet root $1 \%$ & 5.24 & 11.32 & 36.32 & 6.62 & 39.80 & 49.50 & 1.25 \\
\hline P-value & 0.469 & 0.465 & 0.500 & 0.674 & 0.212 & 0.796 & 0.361 \\
\hline Significance & NS & NS & $\mathrm{NS}$ & NS & NS & NS & $\mathrm{NS}$ \\
\hline Betaine $0.1 \%$ & 4.49 & 11.02 & 33.78 & 6.50 & 38.90 & 48.00 & 1.24 \\
\hline Betaine $0.2 \%$ & 4.51 & 11.06 & 34.98 & 6.90 & 41.96 & 45.76 & 1.10 \\
\hline P-value & 1.000 & 0.806 & 0.265 & 0.429 & 0.180 & 0.449 & 0.288 \\
\hline Significance & $\mathrm{NS}$ & $\mathrm{NS}$ & $\mathrm{NS}$ & $\mathrm{NS}$ & $\mathrm{NS}$ & NS & $\mathrm{NS}$ \\
\hline Beet root & 5.16 & 11.26 & 35.96 & 6.53 & 38.38 & 49.88 & 1.32 \\
\hline Betaine & 4.50 & 11.04 & 34.38 & 6.70 & 40.43 & 46.88 & 1.17 \\
\hline P-value & 0.001 & 0.068 & 0.045 & 0.509 & 0.203 & 0.159 & 0.114 \\
\hline Significance & **** & $\mathrm{NS}$ & $*$ & NS & NS & NS & $\mathrm{NS}$ \\
\hline SE Mean & 0.15 & 0.10 & 0.71 & 0.29 & 1.50 & 1.98 & 0.09 \\
\hline
\end{tabular}

Different letters $(\mathrm{a}-\mathrm{b})$ in the same column and comparison indicate significant differences $(\mathrm{P} \leq 0.05)$ * $^{*}$, Significant at $\mathrm{P} \leq 0.05 ; * *$, Significant at $\mathrm{P} \leq 0.01 ;$ N.S, not significant.

RBCs, red blood cells; $\mathrm{Hb}$, hemoglobin; PCV, packed cell volume; WBCs, white blood cells differentiation; N/ L ratio, Neutrophils/ Lymphocyte ratio. 


\section{Aboelfadl M. A. et al.}

Table (4): Means \pm standard error of protein and lipids profile $(\mathrm{mg} / \mathrm{dl})$ of Alexandria growing rabbits fed diets supplemented with different levels of dried red beetroots or commercial betaine.

\begin{tabular}{|c|c|c|c|c|c|c|c|c|c|}
\hline \multirow[b]{2}{*}{ Comparisons } & \multicolumn{4}{|c|}{ Protein profile } & \multicolumn{5}{|c|}{ Lipids profile (mg/dl) } \\
\hline & $\begin{array}{c}\text { TP } \\
(\mathrm{g} / \mathrm{dL})\end{array}$ & $\begin{array}{c}\mathbf{A L} \\
(\mathrm{g} / \mathrm{dL})\end{array}$ & $\begin{array}{c}\text { GL } \\
(\mathbf{g} / \mathbf{d L})\end{array}$ & $\begin{array}{c}\text { AL/GL } \\
\text { ratio }\end{array}$ & $\begin{array}{c}\text { TL } \\
(\mathrm{mg} / \mathrm{dL})\end{array}$ & $\begin{array}{c}\text { Chol } \\
(\mathrm{mg} / \mathrm{dL})\end{array}$ & $\begin{array}{c}\text { TG } \\
(\mathrm{mg} / \mathrm{dL})\end{array}$ & $\begin{array}{c}\text { LDL } \\
\text { (mg/ } \\
\text { dL) }\end{array}$ & $\begin{array}{c}\text { HDL } \\
(\mathrm{mg} / \mathrm{dL})\end{array}$ \\
\hline Control & 6.55 & 3.63 & 2.92 & 1.24 & 267.50 & 103.25 & 118.00 & 29.58 & 40.78 \\
\hline Treatments & 7.15 & 3.78 & 3.37 & 1.12 & 243.19 & 90.76 & 105.88 & 23.93 & 48.78 \\
\hline$P$-value & 0.003 & 0.343 & 0.112 & 0.419 & 0.012 & 0.017 & 0.050 & 0.005 & 0.005 \\
\hline Significance & $* *$ & NS & NS & NS & $*$ & $*$ & $*$ & $* *$ & $* *$ \\
\hline Beet root $0.5 \%$ & 7.24 & 3.88 & 3.36 & 1.15 & 239.50 & 91.00 & 105.75 & 21.58 & 51.03 \\
\hline Beet root $1 \%$ & 7.27 & 3.95 & 3.32 & 1.19 & 235.25 & 83.75 & 100.75 & 23.88 & 49.73 \\
\hline$P$-value & 0.881 & 0.722 & 0.906 & 0.904 & 0.700 & 0.235 & 0.497 & 0.308 & 0.682 \\
\hline Significance & NS & NS & NS & NS & NS & NS & NS & NS & NS \\
\hline Betaine $0.1 \%$ & 7.03 & 3.61 & 3.42 & 1.06 & 254.25 & 95.25 & 110.00 & 26.12 & 46.33 \\
\hline Betaine $0.2 \%$ & 7.05 & 3.68 & 3.37 & 1.09 & 243.75 & 93.00 & 107.00 & 24.15 & 48.03 \\
\hline$P$-value & 0.927 & 0.740 & 0.889 & 0.877 & 0.347 & 0.706 & 0.682 & 0.381 & 0.593 \\
\hline Significance & $\mathrm{NS}$ & $\mathrm{NS}$ & NS & $\mathrm{NS}$ & NS & NS & NS & NS & $\mathrm{NS}$ \\
\hline Beet root & 7.25 & 3.91 & 3.34 & 1.17 & 237.38 & 87.38 & 103.25 & 22.73 & 50.38 \\
\hline Betaine & 7.04 & 3.65 & 3.40 & 1.07 & 249.00 & 94.13 & 108.50 & 25.13 & 47.18 \\
\hline P-value & 0.183 & 0.078 & 0.815 & 0.499 & 0.149 & 0.124 & 0.318 & 0.140 & 0.166 \\
\hline Significance & NS & NS & NS & NS & NS & NS & NS & NS & NS \\
\hline SE Mean & 0.14 & 0.13 & 0.19 & 0.09 & 6.93 & 3.87 & 4.31 & 1.40 & 1.86 \\
\hline
\end{tabular}

Different letters $(a-b)$ in the same column and comparison indicate significant differences $(\mathrm{P} \leq 0.05)$.

*, Significant at $\mathrm{P} \leq 0.05 ; * *$, Significant at $\mathrm{P} \leq 0.01 ;$ N.S, not significant.

TP, total protein; AL, albumin; GL, globulin; AL/GL, Albumin/ Globulin; TL, total lipid; Chol, cholesterol; TG, triglyceride; LDL, low density lipoprotein; HDL, high density lipoprotein. 
Beetroots; Betaine; Productive performance; Lipid profile; Rabbits

Table (5): Means \pm standard error of blood liver and kidney indicators of Alexandria growing rabbits fed diets supplemented with different levels of dried red beetroots or commercial betaine.

\begin{tabular}{|l|c|c|c|c|c|}
\hline \multicolumn{1}{|c|}{ Comparisons } & $\begin{array}{c}\text { AST } \\
\text { (U/L) }\end{array}$ & $\begin{array}{c}\text { ALT } \\
\text { (U/L) }\end{array}$ & $\begin{array}{c}\text { ALP } \\
(\mathbf{U} / \mathbf{L})\end{array}$ & $\begin{array}{c}\text { Creatinine } \\
(\mathbf{m g} / \mathbf{d L})\end{array}$ & $\begin{array}{c}\text { Uric acid } \\
\text { (mg/dL) }\end{array}$ \\
\hline Control & 47.24 & 29.81 & 95.00 & 1.01 & 3.02 \\
Treatments & 39.19 & 24.19 & 110.39 & 0.78 & 2.84 \\
P-value & 0.002 & 0.006 & 0.011 & 0.000 & 0.410 \\
\hline Significance & $* *$ & $* *$ & $*$ & $* * *$ & $\mathrm{NS}$ \\
\hline Beet root 0.5\% & 37.55 & 23.62 & 115.03 & 0.83 & 2.91 \\
Beet root 1\% & 34.80 & 21.99 & 111.13 & 0.82 & 2.87 \\
P-value & 0.314 & 0.478 & 0.571 & 0.806 & 0.888 \\
\hline Significance & $\mathrm{NS}$ & $\mathrm{NS}$ & $\mathrm{NS}$ & $\mathrm{NS}$ & $\mathrm{NS}$ \\
\hline Betaine 0.1\% & 42.36 & 25.22 & 107.30 & 0.74 & 2.82 \\
Betaine 0.2\% & 42.03 & 25.94 & 108.10 & 0.75 & 2.77 \\
P-value & 0.904 & 0.751 & 0.907 & 0.883 & 0.851 \\
\hline Significance & $\mathrm{NS}$ & $\mathrm{NS}$ & $\mathrm{NS}$ & $\mathrm{NS}$ & $\mathrm{NS}$ \\
\hline Beet root & 36.17 & 22.80 & 113.08 & 0.82 & 2.89 \\
Betaine & 42.20 & 25.58 & 107.70 & 0.74 & 2.80 \\
P-value & 0.006 & 0.098 & 0.277 & 0.044 & 0.620 \\
\hline Significance & $* *$ & $\mathrm{NS}$ & $\mathrm{NS}$ & $*$ & $\mathrm{NS}$ \\
\hline SE Mean & 1.70 & 0.87 & 2.44 & 0.03 & 0.08 \\
\hline
\end{tabular}

Different letters $(a-b)$ in the same column and comparison indicate significant differences $(\mathrm{P} \leq$ 0.05 ). *, Significant at $\mathrm{P} \leq 0.05$; **, Significant at $\mathrm{P} \leq 0.01$; N.S, not significant.

AST, Aspartate Transaminase; ALT, Alanine aminotransferase; ALP, Alkaline phosphatase.

Table (6): Economic efficiency of the experimental Alexandria growing rabbits as affected by different supplementations level of dried red beetroots or commercial betaine during 4 and 9 weeks of age.

\begin{tabular}{|c|c|c|c|c|c|c|}
\hline & \multirow{3}{*}{ Items } & \multicolumn{5}{|c|}{ Experimental treatments } \\
\hline & & \multirow{2}{*}{$\begin{array}{c}\text { Cont } \\
\text { rol }\end{array}$} & \multicolumn{2}{|c|}{ Dried red beetroot } & \multicolumn{2}{|c|}{ Commercial betaine } \\
\hline & & & $\begin{array}{c}0.5 \mathrm{~kg} / 100 \mathrm{Kg} \\
(0.5 \%)\end{array}$ & $\begin{array}{c}1 \mathrm{~kg} / 100 \mathrm{Kg} \\
(1.0 \%)\end{array}$ & $\begin{array}{c}0.1 \mathrm{~kg} / 100 \mathrm{~kg} \\
0.1 \%\end{array}$ & $\begin{array}{c}0.1 \mathrm{~kg} / 100 \mathrm{~kg} \\
0.2 \%\end{array}$ \\
\hline \multirow{3}{*}{ Feed } & Total intake (kg/rabbit) & 3.65 & 3.76 & 3.77 & 3.73 & 3.78 \\
\hline & Price/kg (L.E) & 4.80 & 4.90 & 5.00 & 4.94 & 5.08 \\
\hline & Total feed cost (L.E) & 17.52 & 18.42 & 18.85 & 18.43 & 19.20 \\
\hline \multirow{3}{*}{ Meat } & Weight gain (kg/rabbit) & 1.185 & 1.31 & 1.30 & 1.28 & 1.29 \\
\hline & Price/kg (L.E) & 34 & 34 & 34 & 34 & 34 \\
\hline & Total Revenue & 40.29 & 44.30 & 44.20 & 43.52 & 43.86 \\
\hline \multicolumn{2}{|c|}{ Net Revenue $\quad$ (L.E) } & 22.77 & 25.88 & 25.35 & 25.09 & 24.66 \\
\hline \multirow{2}{*}{\multicolumn{2}{|c|}{$\begin{array}{l}\text { Economic efficiency } \\
\text { Relative economic efficiency }(\%)\end{array}$}} & 129.97 & 140.50 & 134.48 & 136.10 & 128.40 \\
\hline & & 100 & 108.10 & 103.47 & 104.72 & 98.79 \\
\hline
\end{tabular}

The price of red beetroot algae is about 24.0 LE, betaine is 140.0 LE in 2020 . 


\section{REFERENCES}

Abd El-Azeem, A.; Ahmed, E.; AlSagheer, A. A.; Daader, A. H.; Bassiony, S. M. 2019. Effect of dietary supplementation with betaine, thyme oil and their mixtures on productive performance of growing rabbits. Zagazig Journal of Agricultural Research, 46(3): 815-828.

Abd El-Moniem, E. A.; Daader, A. H.; Al-Sagheer, A. A.; Gabr, H. A. 2016. Effect of vitamin $\mathrm{C}$, vitamin $\mathrm{E}$ or betaine addition on alleviation of heat stress impacts on growing rabbits. Zagazig Journal Agriculture Research. 43(5):1601-1613.

Abedo, A. A.; El-Badawi, A. Y.; Hassan, A. A. 2012. Sugar beet pulp as an energetic feed in growing rabbit diets. Egyptian Journal Nutrition and Feeds. 15(3): 513-522.

Aboul-Ela, S. S.; Reda, F. M. 2016. Influence of partial and total substitution yellow corn grains with sugar beet pulp on growing rabbits performance. Zagazig Journal Agriculture Research. 4(6A).

Ashour, E. A.; Alagawany, M.; Reda, F. M.; Abd El-Hack, M. E. 2014. Effect of supplementation of Yucca schidigera extract to growing rabbit diets on growth performance, carcass characteristics, serum biochemistry and liver oxidative status. Asian Journal of Animal Veterinary Advanced. 9(11): 732-742.

Awad, M. A. 2019. Effects of betaine chloride on performance, physiological and carcass characteristics in diet of broiler chickens under the environmental conditions of Egypt. Msc. Thesis, Poultry production, Faculty of Agriculture, Alexandria University.
Belabbas, R.; María de la Luz García; Hacina Ainbaziz; Nadia Benali; Ali Berbar, A.; Zoubeida Boumahdi; María José Argente 2019. Growth performances, carcass traits, meat quality and blood metabolic parameters in rabbits of local Algerian population and synthetic line. Veterinary World. 12: 55- 62

Chand, N.; Naz, S.; Maris, H.; Khan, R. U.; Khan, S.; Qureshi, M. S. 2017. Effect of betaine supplementation on the performance and immune response of heat stressed broilers. Pakistan Journal Zoology. 49(5): 1857-1862.

Duncan, D. B. 1955. Multiple Rang and Multiple F-Test Biometrics. 11:1-42.

El-Raffa, A. M.; Youssef, Y. K.; Iraqi, M. M.; Khalil, M. H.; García, M. L.; Bselga, M. 2005. Developing rabbit lines for meat production in Egypt and Saudi Arabia: Overview, synthesizing plan, descriptive performance and future prospects. In Proc.: The $4^{\text {th }}$ International Conference on Rabbit Production in hot climates. Genetics Section N4. Sharm El-Sheik, Egypt, 24-27 February. ERSA.

El-Shinnawy, A. M. 2015. Effect of betaine supplementation to methionine adequate diet on growth performance, carcass characteristics, some blood parameters and economic efficiency of broilers. Journal of Animal and Poultry Production. 6(1): 27-41.

El-Taweel, A. A. F. 2010. Studies on using sugar beet pulp in rabbit diets. MSC. Thesis, Faculty of Agriculture, Zagazig University, Egypt.

Elwasife, K.; Abdel Aziz, I.; Shabat, M.; Shahwan, O.; El Hamidi, A. 2015. Effects of noise on rabbit's blood. European Journal Biophysics, 3(2): $10-13$ 
Beetroots; Betaine; Productive performance; Lipid profile; Rabbits

Feldman, U.; Curdt, W.; Landi, E.; Wilhelm, K. 2000. Identification of spectral lines in the 500-1600 å wave length range of highly ionized $\mathrm{Ne}, \mathrm{Na}$, $\mathrm{Mg}, \mathrm{Ar}, \mathrm{K}, \mathrm{Ca}, \mathrm{Ti}, \mathrm{Cr}, \mathrm{Mn}, \mathrm{Fe}, \mathrm{Co}$, and Ni emitted by flares $\left(T_{e} \geq \times 10^{6} \mathrm{~K}\right)$ and their potential use in plasma diagnostics. The Astrophysical Journal, 544:508-521.

Figueroa, S.; Ciria, G.; Elisa, M.; Valenzuela, S. 2018. Glycine betaine rather than acting only as an osmolyte also plays a role as regulator in cellular metabolism. Biochimie. 147, 89-97. doi: 10.1016/j.biochi.2018.01.002

Harr, K. E. 2002. Clinical chemistry of companion avian species: A Review. Veterinary Clinical Pathology. 31, 140-151

Hassan, R. A.; Ebeid, T. A.; Abd ElLateif, A. I.; Ismail, N. B. 2011. Effect of dietary betaine supplementation on growth, carcass and immunity of New Zealand White rabbits under high ambient temperature. Livestock Science. 135:103-109

Hayam, M. A. Abo EL-Maaty; Sara Kh. Sherif; Lina S. A. Foda 2017. Efficiency of Utilization of Sugar Beet Tops Hay and Prebiotic in Diets of Growing Rabbits. Asian Journal of Animal and Veterinary Advances, 12 (2): $71-79$

Hayam, M. A. Abo El-Maaty; Sara Kh. Sherif; Lina S. A. Foda 2018. Dietary Sugar Beet Tops and Prebiotic Effect on Nutrient Digestibility, Caecal Activity and Organ Histology of Weaning Rabbits. Journal Agriculture Science. 10(3): 162-177

Hussein, A. S.; Al Ghurair, J.; John, P. G. K. ; Habib, H. M.; Sulaiman, M. 2016. Graded levels of sugar syrup in broiler rations and its effect on growth performance and blood biochemical parameters. Animal Nutrition, 3: 1-6

Kaneko, J. J. 1989. Clinical biochemistry of domestic animals. Academic Press, New York.

Kurchaeva, E. E., Vostroilov, A. V.; Artemov, E. S.; Maksimov, I. V. 2019. Improvement of rabbit productivity using probiotics and herbal supplements. Conference on Innovations in Agricultural and Rural development. Earth and Environmental Science. 341, 012051 doi:10.1088/1755-1315/341/1/012051

Lee, M. T.; Lin, W. C.; Lee, T. T. 2017. Antioxidant capacity of phytochemicals and their potential effects on oxidatus status in animals: A review. Asian-Australian Journal Animal Science. 30(3): 299- 308

Li, S.; Zhao, M.; Jiang, T.; Lv, W.; Gao, S.; Zhou, Y.; Miao Z. 2018. Growth performance and antioxidant status of growing rabbits fed on diets supplemented with Eucommia ulmoides leaves. World Rabbit Science. 26: 35-41.

Moniello, G.; Bovera, F.; Solinas, I. L.; Piccolo, G.; Pinna, W.; Nizza, A. 2005. Effect of age and blood collection site on the metabolic profile of Ostriches. South African Journal of Animal Science, 35: 268-272

Mroczek, A.; Kapusta, I.; Janda, B.; Janiszowska, W. 2012. Triterpene saponin content in the roots of red beet (Beta vulgaris L.) cultivars. Agriculture Food Chemistry. 60(50): 12397-12402.

Nestora, S.; Merlier, F.; Prost, E.; Haupt, K.; Rossi, C.; Tse, S. B. B. 2016. Solid-phase extraction of betanin and isobetanin from beetroot extracts using a dipicolinic acid molecularly imprinted polymer. 
Aboelfadl M. A. et al.

Journal Chromatography. A, 1465:4754

NRC 1994. National Research Council: Nutrient requirements of poultry: National Academies Press; $9^{\text {th }}$ rev. edn. National Academy Press, Washington DC, USA.

NseAbasi, N. Etim; Mary, E. W.; Akpabio, U.; Offiong, E. E. A. 2014. Haematological parameters and factors affecting their values. Agriculture Science. 2: 37-47.

Oloruntola, O. D.; Ayodele, S. O.; Agbede, J. O.; Oloruntola, D. A.; Ogunsipe, M. H.; Omoniyi, I. S. 2016. Effect of Alchornea cordifolia leaf meal and enzyme supplementation on growth, haematological, immune stimulatory and serum biochemical response of rabbits. Asian Journal of Life sciences, 5: 190-195.

Rabeh, N. M. 2015. Effect of red beetroot (Beta vulgaris L.) and its fresh juice against carbon tetrachloride induced hepatotoxicity in rats. World Applied Sciences Journal, 33(6): 931938.doi:10.5829/idosi.wasj.2015.33.06 .260

Ratriyanto, A.; Mosenthin, R.; Bauer, E.; Eklund, M. 2009. Metabolic, osmoregulatory and nutritional functions of betaine in monogastric animals. Asian-Australasian Journal of Animal Sciences, 22(10): 1461-1476.

Riad, S. A.; Safaa, H. M.; Mohamed, F. R.; Siam, S. S.; El-Minshawy, H. A. 2010. Influence of probiotic, prebiotic and/or yeast supplementation in broiler diets on the productivity, immune response and slaughter traits. Journal of Animal and Poultry Production. 1(2): 45-60.

Saeed, M.; Babazadeh, D.; Naveed, M.; Arain, M. A.; Hassan, F. U.; Chao, S. 2017. Reconsidering betaine as a natural anti-heat stress agent in poultry industry: A review. Tropical Animal Health Production. 49, 1329-1338.

Sakomura, N. K.; Barbosa, N. A. A.; Longo, F. A.; Silva, E. P. da; Bonato, M. A.; Fernandes, J. B. K. 2013. Effect of dietary betaine supplementation on the performance, carcass yield, and intestinal morphometrics of broilers submitted to heat stress. Brazilian Journal Poultry Science. 15: 105-112.

Sara Kh. Sherif ; Fatma A. Elgohary; Hayam A. Abo El-Maaty 2019. Response to $\beta$-pro dietary supplementation in growing rabbits reared at different stocking densities under hot environmental conditions. Egypt Poultry Science Journal. 39(I): 133-151.

SAS 2004. SAS/STAT User's Guide. Statistics, version 8. Cary, NC: SAS Institute.

Shehata, S. A.; Bahgat, L. B. 2006. Effect of sugar beet pulp and molasses on growth performance of rabbits. Zagazig Journal Agriculture Research. 33(5): 903-913

Shimaa, A. Amer; Anaam E. Omar; Wafaa A. M. Mohamed; Heba S. A. Gharib; Wafaa A. El-Eraky 2018. Impact of betaine supplementation on the growth performance, tonic immobility, and some blood chemistry of broiler chickens fed normal and low energy diets during natural summer stress. Zagazig Veterinary Journal. 46(1): 37-50.

Valenzuela-Grijalva, N. V.; PinelliSaavedra, A.; Muhlia- Almazan, A.; Domínguez-Díaz, D.; González-Ríos, H. 2017. Dietary inclusion effects of phytochemicals as growth promoters in animal production. Journal Animal 


\section{Beetroots; Betaine; Productive performance; Lipid profile; Rabbits}

Science Technology. $58: \quad 8$. $\quad$ Yilkal, T. 2015. Important antidoi.org/10.1186/s40781-017-0133-9

Wang, Y. Z.; Xu, Z. R.; Feng, G. 2004.

The effect of betaine and DLmethionine on growth performance and carcass characteristics in meat ducks. Animal Feed Science Technology. 116: 151-159.

Xu, L.; Huang, D.; Hu, Q.; Wu, J.; Wang, Y.; Feng, J. 2015. Betaine alleviates hepatic lipid accumulation via enhancing hepatic lipid export and fatty acid oxidation in rats fed with a high-fat diet. Brazilian Journal nutritional substances and inherent toxicants of feeds. Food Science and Quality Management. 36: 40-47

Yusuf, M. S.; El Nabtiti, A. A.; Marwa A. Hassan; Mandour, M. A. 2018. Supplementary outcomes of betaine on economic and productive performance, some biochemical parameters, and lipoprotein lipase gene expression in finishing male broilers. International Journal of Veterinary Science and Medicine, 6(2): 213-218.

Nutrition. 113, 1835-1843.

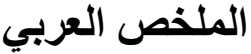

تأثير إضافة البنجر الأحمر أو البيتاين على الأداء الإتتاجي وصور الام والكفاءة الاقتصادية

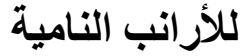

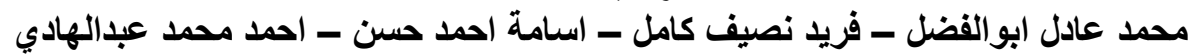

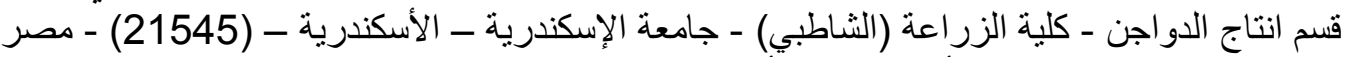

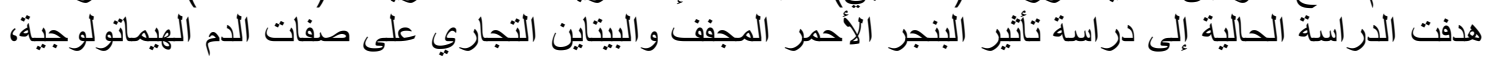

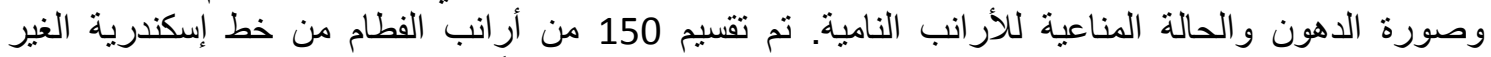

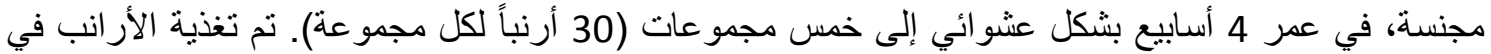

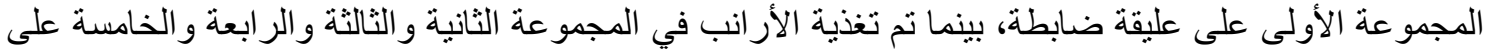

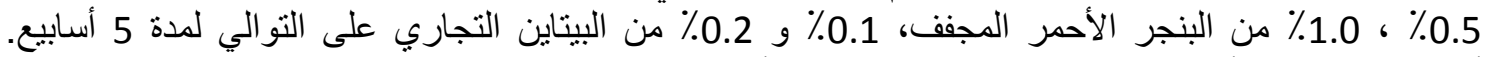

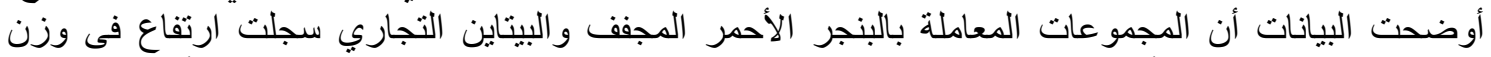

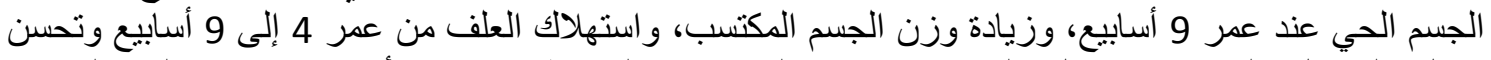

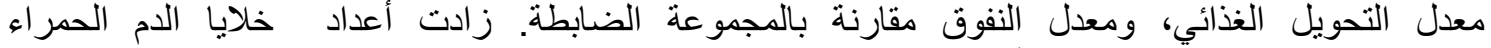

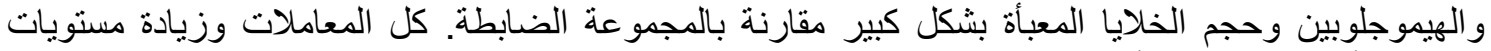

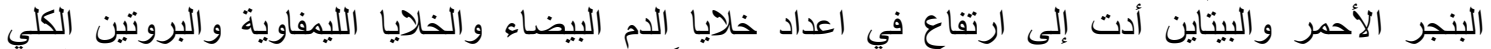

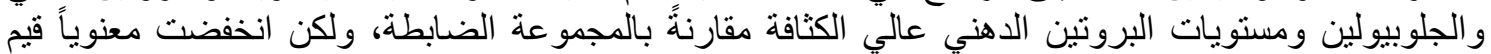

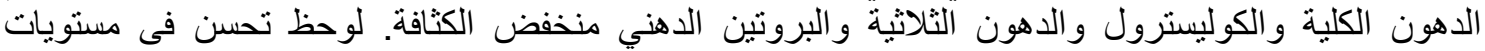

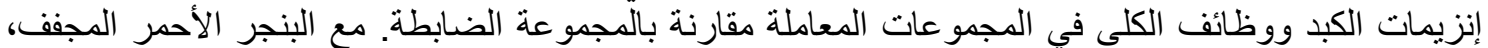

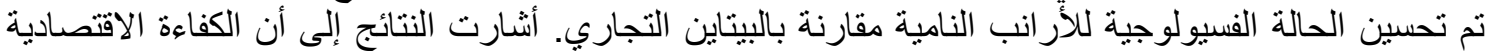

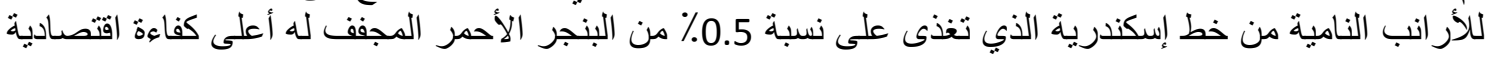

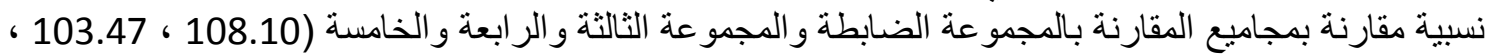

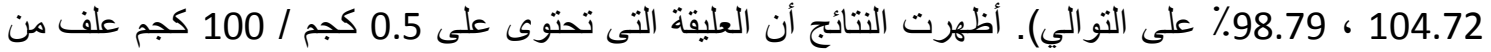

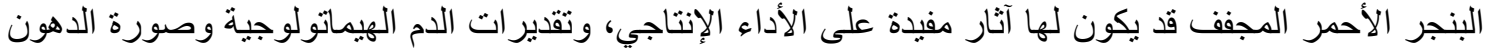
و الكفاءة الاقتصادية للأر انب النامية. الكلمات الدالة: البنجر الأحمر، البيتاين، الأداء الإنتاجي، صورة الدهون، الأر انب 